\title{
O Bom Momento da Ciência Básica Brasileiva
}

$\mathbf{E}$ STE NÚMERO DOS "ARQUIVOS" traz, acredito que pela primeira vez na sua história, uma coletânea exclusiva de trabalhos científicos ditos "básicos", gerados em laboratórios de pesquisa de instituições nacionais, essencialmente enfocando aspectos básicos ou fundamentais da endocrinologia e metabologia, não necessariamente "clínicos". Neste aspecto, vale ressaltar o título do editorial seguinte, da nossa editora-convidada, Doris Rosenthal, "Quando a Endocrinologia Não é Clínica".

Estes trabalhos podem, a primeira vista, parecer menos interessantes do que aqueles abordando os aspectos clínicos e práticos do diagnóstico e tratamento das doenças endócrinas, as discussões de casos e as revisões e atualizações de temas clínicos, mas uma leitura mais atenta, que eu enfaticamente recomendo a todos os colegas, irá mostrar uma quantidade (e qualidade) de informações fundamentais para a integração de conhecimentos clínicos prévios e embasar muitos outros dados esparsos ou facilmente voláteis em nossas cabeças. Isto para não reforçar o jargão de que é do conhecimento básico, fundamental e descompromissado que advém a estruturação do conhecimento clínico aplicado, dirigido e orientado.

Esta publicação, encomendada há tempos à nossa cara Doris Rosenthal, presidente do Departamento de Endocrinologia Básica da SBEM, chega às mãos dos colegas em momento dos mais oportunos, quando nossa ciência básica parece estar sendo vista com mais atenção pela comunidade científica internacional e adquirindo sua merecida e longamente esperada respeitabilidade.

Não é por acaso que a revista Nature, no seu número de 13 de julho de 2000 , apresenta um trabalho hercúleo, sendo inclusive matéria de capa da revista, assinado por 116 cientistas de 34 centros de pesquisa brasileiros e coordenados pela FAPESP. Este artigo, que foi e continua sendo comentado em várias revistas e jornais do país e do exterior, descreve o seqüenciamento e a caracterização do genoma da Xylella fastidiosa, a "praga do amarelinho", a primeira bactéria que ataca plantas a ter seu genoma decodificado. Este feito tem aplicação prática senão imediata pelo menos a médio prazo, na medida em que acena com a possibilidade de se encontrar meios para o extermínio de uma praga da lavoura da citricultura, permitindo melhorar a qualidade e a quantidade de nossa produção de laranjas, com inegável retorno sócio-econômico. Não foi também sem razão que esta comunidade de pesquisadores, parte de um consórcio maior, ganhou a tarefa de decifrar o código genético de uma praga da uva, infestação que desafia a indústria vinícola do norte da California, EUA, produtora de vinhos de renomada qualidade.

Mais do que isso, um projeto paralelo, também parte de um consórcio internacional, o Genoma Câncer, está sendo desenvolvido com rapidez assustadora e traz para o país o foco das atenções de cientistas internacionais, pela sua inquestionável possibilidade de resolver questões médicas até há pouco indecifráveis. 
O momento é excelente, também, pela atenção que vem sendo dada ao trabalho desta gente pelo governo e pelas instituições de fomento a pesquisa, com investimentos antes inimagináveis na nossa sociedade. A FAPESP (e fundações congêneres de outros estados do país), o Ministério da Saúde, o CNPq e outros, estão, finalmente, investindo mais e mais na pesquisa básica brasileira nestes últimos 15 ou 20 anos, em especial agora que sua credibilidade tem sido mais amplamente reconhecida internacionalmente, embora tivesse sempre sido séria e eficiente. $\mathrm{O}$ aporte de recursos previsto para investimentos em pesquisa no Brasil deve passar da ordem dos $0,5 \%$ do nosso PIB para $0,6 \%$ ou $0,7 \%$, nivelando-se com os investimentos estatais de países mais desenvolvidos, como Alemanha e Estados Unidos $(0,8$ e $0,9 \%$, respectivamente). Mesmo antes disso, dados estatísticos recentes tem mostrado que a contribuição da pesquisa nacional frente à produção mundial, avaliada por suas publicações em revistas científicas internacionais, saltou de $0,4 \%$ para $1,2 \%$. Tudo nos leva a crer que devemos estar trilhando o caminho acertado.

Os colegas que colaboraram nesta edição, espalhados por vários laboratórios de pesquisa brasileiros, são exemplos de cientistas que também tem seu mérito reconhecido internacionalmente. Apenas por curiosidade e querendo comprovar com números o que já sabia de fato, fiz uma pesquisa no PubMed / Medline procurando precisar o volume de publicações destes colegas nos últimos 5 anos. Sem qualquer surpresa, e com a reconfortante satisfação do "eu já imaginava", constatei que a quase totalidade dos autores principais dos trabalhos aqui apresentados, ou dos responsáveis pelos laboratórios onde as pesquisas foram conduzidas, têm, cada um deles, mais de 10 trabalhos publicados em revistas indexadas neste período.

Assim, é com muita satisfação que eu passo a vocês a leitura deste valioso e informativo material, produzido por colegas que, por razões variadas, têm sido menos freqüentemente expostos aos nossos olhos clínicos, mas que espero possam vir a sê-lo mais amiúde, daqui para a frente.

Por último, mas não menos importante, (um mal português para "last but not the least"), uma palavra de agradecimento à nossa editora convidada. Talvez vocês não saibam, mas podem imaginar o quanto é difícil e trabalhoso coordenar uma publicação que envolve a colaboração de muitas pessoas num período de tempo sempre restrito.

Não me recordo exatamente quando conversei a primeira vez com a Doris para elaborarmos esta edição; provavelmente já faz mais de 18 , talvez 24 meses, e a expectativa era a de publicarmos este materæal na edição de Agosto de 2000, como de fato fizemos. Dentro do cronograma de trabalho, entretanto, ela e seus convidados mostraram um "timing" perfeito; não somente não atrasaram em nenhum momento como me apresentaram todo o material pronto, corrigido e pré-editado muito antes do prazo. Parabéns a ela e aos colaboradores, que não só pela qualidade de suas pesquisas mas também pela disponibilidade e, principalmente pelo respeito à pontualidade, merecem nosso respeito e consideração.

Não tenho dúvidas que esta iniciativa de publicar uma edição dos "Arquivos" contendo apenas ciência básica, encontrará respaldo entre nosso público leitor e, assim, permito-me, manter abertas as portas da nossa revista para receber cada vez mais publicações na área da endocrinologia e metabologia, destes e de outros colegas cientistas básicos, permitindo que seus resultados e idéias possam ser mesclados aos conhecimentos oferecidos nas publicações de teor mais clínico; este balanço, espero, deverá propiciar novas perguntas e alimentar novas pesquisas de interesse comum.

Posso não estar sendo exatamente fiel às palavras, mas nesta situação de aparente dicotomia da ciência, parece que se encaixa muito bem uma frase atribuída a Louis Pasteur: “ ... não existe ciência aplicada, mas somente aplicações da ciência". 